\title{
Cotton (Gossypium hirsutum) Cultivars Exhibiting Tolerance to the Reniform Nematode (Rotylenchulus reniformis)
}

\author{
Julie A. Blessitt, ${ }^{1}$ Salliana R. Stetina, ${ }^{2}$ Ted P. Wallace, ${ }^{1}$ \\ Peggy T. Smith, ${ }^{3}$ and Gabriel L. Sciumbato ${ }^{3}$ \\ ${ }^{1}$ Department of Plant and Soil Sciences, Mississippi State University, Box 9555, Mississippi State, MS 39762, USA \\ ${ }^{2}$ Crop Genetics Research Unit, Agricultural Research Service, USDA, P.O. Box 345, Stoneville, MS 38776, USA \\ ${ }^{3}$ Delta Research and Extension Center, Mississippi State University, P.O. Box 197, Stoneville, MS 38776, USA
}

Correspondence should be addressed to Salliana R. Stetina, sally.stetina@ars.usda.gov

Received 27 December 2011; Revised 6 February 2012; Accepted 6 February 2012

Academic Editor: M. Tejada

Copyright (c) 2012 Julie A. Blessitt et al. This is an open access article distributed under the Creative Commons Attribution License, which permits unrestricted use, distribution, and reproduction in any medium, provided the original work is properly cited.

\begin{abstract}
A field study was conducted over a two-year period (2006-2007) at the Delta Research and Extension Center, Stoneville, MS, USA to screen selected entries in the 2006 Mississippi Cotton Variety Trials for tolerance to the reniform nematode (Rotylenchulus reniformis). Trials were conducted in nonirrigated fields with primarily sandy loam soils. Though some variability was noted between test locations and years, six of 13 cotton (Gossypium hirsutum) cultivars tested were considered tolerant to the reniform nematode: "Cropland Genetics 3520 B2RF," "DynaGrow 2520 B2RF," "Stoneville 5242 BR," "Stoneville 5599 BR," "Deltapine 488 BG/RR," and "Fibermax 960 B2R." Of these, the first three exhibited yields similar to the productive cultivar "Deltapine 445 BG/RR" in all environments. Though they will not suppress the reniform nematode population, these cultivars can help reduce economic losses attributed to this pathogen in the Midsouth region of the USA.
\end{abstract}

\section{Introduction}

When planting any crop, it is important to consider potential losses due to susceptibility to pests. Upland cotton (Gossypium hirsutum) is an important crop in Mississippi. In 2008, cotton losses in Mississippi attributed to nematodes were at $10 \%$ ( 81,250 bales), the majority $(8 \%)$ due to the reniform nematode (Rotylenchulus reniformis), with an approximate loss of 65,000 bales [1]. This estimate ranks reniform nematode as the most damaging nematode threat to cotton in the state.

Rotation to nonhost crops and application of nematicides have been used for reniform nematode population management. Rotation to a non-host crop reduces the nematode population in the soil [2-4], though the population may rebound quickly when a susceptible crop is planted the following cropping season [5]. Management through chemical treatment of infested soils remains a useful control practice for reniform nematode, though use of nematicides is often cost prohibitive. Nematicides are dangerous to handle, can be fatal, pose a risk to ground water, and are toxic to wildlife
[6]. These concerns have resulted in a gradual reduction in the number of products available, including discontinuation of the popular nematicide aldicarb [7]. If highly susceptible cultivars could be avoided in nematode-infested areas and replaced with tolerant or resistant cultivars, some of the risks associated with nematicide use could be avoided.

Unfortunately, no commercial cotton cultivars with resistance to reniform nematode exist $[3,8]$. It will likely be years before novel genes for resistance recently identified in the related Gossypium species G. longicalyx [9], G. aridum [10], and G. barbadense [11] are available to growers.

The absence of resistance has shifted some focus to finding tolerance to the reniform nematode in G. hirsutum. Tolerance can be defined as the "ability of a plant to sustain the effects of a disease without dying or suffering serious injury or crop loss" [12]. Tolerant plants support reproduction by nematodes while sustaining lower yield losses than other cultivars having comparable levels of nematode infection [13]. Therefore, identification of tolerance requires an analysis and comparison of cultivars for yield performance under field conditions [13-21]. 
In previous years, researchers from several labs attempting to identify reniform nematode tolerant cultivars have had very limited success. Usery et al. [21] saw some possible tolerance in two upland cotton cultivars, Stoneville 4793 and Suregrow 521R, but their results were inconsistent across years and locations. Cook et al. [15] identified possible tolerance in only a few high yielding breeding lines tested. Stetina et al. [20] identified three possible tolerant cultivars ("Suregrow 215 BR," "Paymaster 1218 BR," and "Deltapine 449 BR") out of the 39 lines tested, but suggested that tolerant lines, in general, were not widely available. Germplasm lines characterized as having reniform nematode tolerance have been released [15, 22, 23]. However, as most commercial cultivars have a relatively short "shelf life," there is a continual need to evaluate new commercial cultivars and germplasm releases for tolerance.

This study was undertaken to identify cotton cultivars that exhibit tolerance to the reniform nematode in the Mississippi Delta. Though tolerant cultivars will not help manage nematode populations in the long term, they could help minimize economic losses in the short term. Readily available, tolerant cultivars could provide immediate relief for a growing economic problem until a time when true resistance becomes available in commercial cultivars.

\section{Materials and Methods}

Field experiments were conducted during the 2006 and 2007 growing seasons to evaluate selected cultivars from the 2006 Mississippi Cotton Variety Trials [24] for tolerance to the reniform nematode. Fields selected for this study had a history of continuous cotton for several years and were characterized as having a high natural infestation of reniform nematodes. In the fall prior to planting, reniform nematode populations met or exceeded the treatment threshold level of $16.2 / \mathrm{cm}^{3}$ soil [25-27]. Experiments were conducted at four different sites at the Delta Research and Extension Center (DREC), Stoneville, MS. In 2006, experiments were conducted in Field 4 and the Barn Field, and in 2007 the experiments were located in Field 1 and Field 12.

Although water was available, supplemental irrigation was not required. Seasonal precipitation and soil temperature $(10 \mathrm{~cm}$ depth $)$ data were obtained from the Delta Agricultural Weather Center at Mississippi State University (http://www.deltaweather.msstate.edu/historic_ag_weather_ data/historic_ag_weather_data.htm). Rainfall amounts and seasonal patterns during the 2006 growing season differed from those observed in 2007 (Figure 1). Less rain fell during 2006, particularly early in the season. In contrast, 2007 had more precipitation and abundant rainfall during July. Minimum (Figure 2) and maximum (Figure 3 ) soil temperatures varied little between years.

According to the United States Department of Agriculture Natural Resources Conservation Service (http:// websoilsurvey.nrcs.usda.gov/app/WebSoilSurvey.aspx), Field 4 consisted of a Bosket very fine sandy loam (Alfisols Udalfs Hapludalfs Mollic; fine loamy, mixed, active, thermic) and a Commerce series soil (Inceptisols Aquepts Endoaquepts

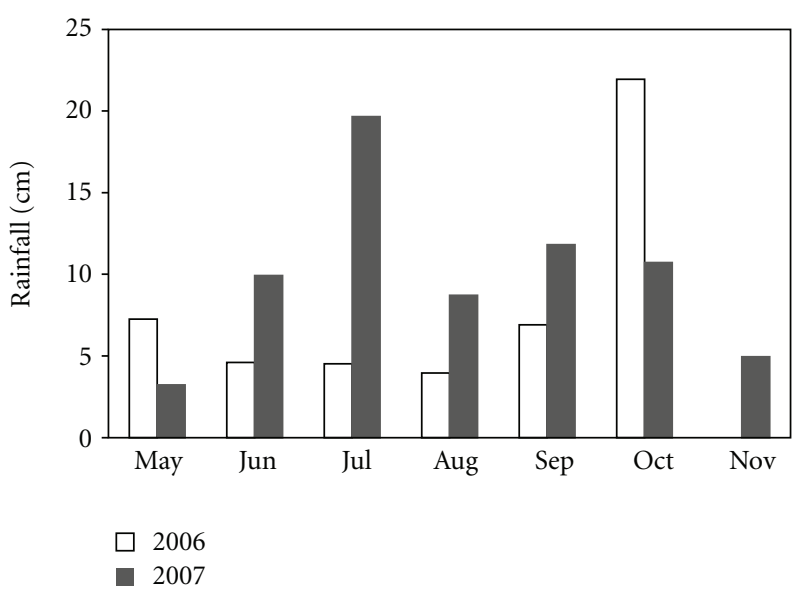

FIGURE 1: Mean monthly rainfall during the 2006 and 2007 growing seasons at the Mississippi State University Delta Research and Extension Center in Stoneville, MS.

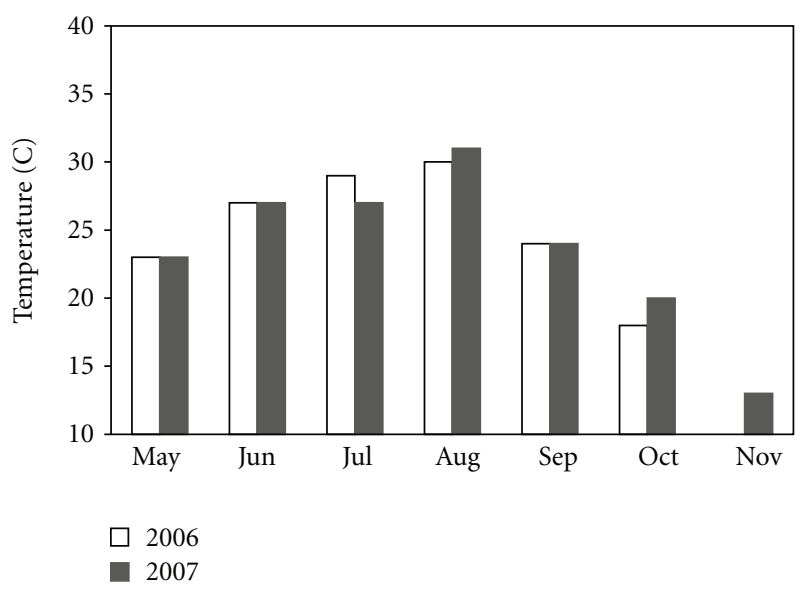

FIGURE 2: Mean monthly minimum soil temperature at a depth of $10 \mathrm{~cm}$ during the 2006 and 2007 growing seasons at the Mississippi State University Delta Research and Extension Center in Stoneville, MS.

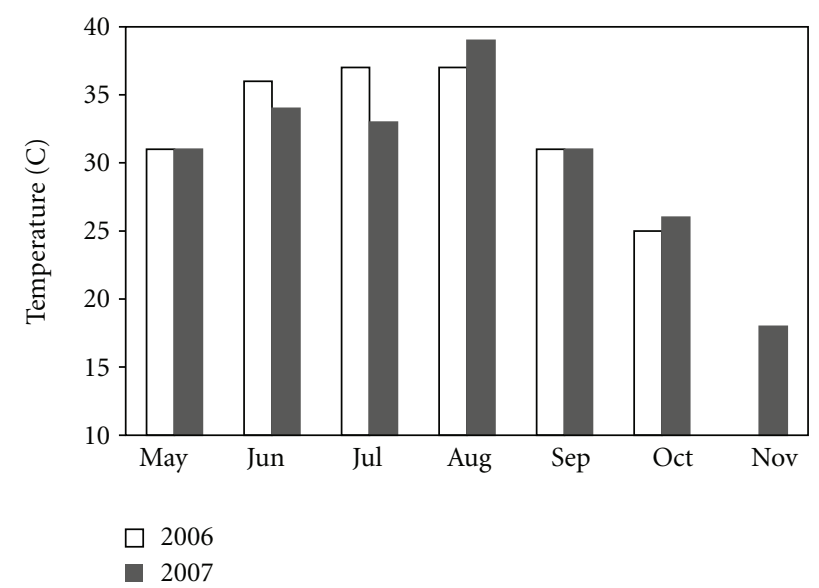

FIGURE 3: Mean monthly maximum soil temperature at a depth of $10 \mathrm{~cm}$ during the 2006 and 2007 growing seasons at the Mississippi State University Delta Research and Extension Center in Stoneville, MS. 
Fluvaquentic; fine silty, mixed, superactive, nonacid, thermic). Field 1 was a Bosket very fine sandy loam. Field 12 consisted of Beulah very fine sandy loam (Inceptisols Udepts Dystrudepts Typic; coarse loamy mixed, active, thermic), Bosket very fine sandy loam, and Commerce series soils. The Barn Field contained both Bosket series and Commerce series soils.

Reniform nematode distribution is not necessarily uniform across a field, so experiments were arranged in a splitplot design to increase precision in measuring effects of the nematicide (subplot treatment) on crop yield. The main plot consisted of 13 cotton cultivars. Eleven were chosen at random to represent the major seed companies participating in the 2006 Mississippi Cotton Variety Trials [24]: "Croplan Genetics 3520 B2RF," "Deltapine 445 BG/RR," "Deltapine 449 BG/RR," "Deltapine 455 BG/RR," "Deltapine 488 BG/RR," "DynaGrow 2520 B2RF," "Fibermax 960 B2R,” "Phytogen 370 WR," "Phytogen 485 WRF," "Stoneville 5242 BR," and "Stoneville 5599 BR." Also included were cultivars Deltapine 20B, which supported high levels of reniform nematode reproduction in previous tests [20], and DES119, an obsolete conventional cultivar considered tolerant to reniform nematode [28]. Commercial cultivar Deltapine 445 BG/RR was designated as the check cultivar for yield based upon its superior performance in the 2005 Mississippi Cotton Variety Trials [29]. All cultivars were developed and have been marketed for the growing conditions represented by DREC trial sites. Subplots consisted of nontreated plots and nematicide-treated plots receiving aldicarb (Temik 15 G, Bayer CropScience, Durham, NC) at $0.84 \mathrm{~kg}$ of active ingredient per hectare (a.i./ha) applied in furrow at planting followed by a side-dress application of $1.17 \mathrm{kga}$ a.i./ha at pinhead square. The application of aldicarb at planting time under ideal conditions is sufficient to keep reniform nematode levels manageable for approximately six weeks [30]. The subplot treatment allowed for determination of nematode reproduction values and provided a basis for comparison of yields in nematicide-treated versus nontreated plots within cultivars for interpolation of tolerance.

Main plots were replicated 5 times in each field in a randomized complete block arrangement. Main plots consisted of eight $12.2 \mathrm{~m}$ rows spaced $1 \mathrm{~m}$ apart with 13 seed planted per row meter using a 4-row cone plot-type Almaco planter (Almaco, Nevada, IA). Subplots were four rows. Prior to planting, trifluralin (Trifluralin 4 EC, Albaugh, Inc., Ankeny, IA; $1.2 \mathrm{~L} / \mathrm{ha}$ ) was applied to all fields for weed control. After planting, a combination of cultivation and herbicides recommended for use in conventional cotton in Mississippi was used as needed to manage weeds. Herbicides used included prometryn (Caparol 4 L, Syngenta Crop Protection, Inc., Greensboro, NC), fluometuron (Cotoran 4 L, Makhteshim Agan of North America, Inc., Raleigh, NC), MSMA (MSMA 6.6, Drexel Chemical Company, Memphis, TN), lactofen (Cobra 2 EC, Valent U.S.A. Corporation, Walnut Creek, CA), pyrithiobac sodium (Staple LX, DuPont Crop Protection, Wilmington, DE), 2-pyridinesulfonamide (Envoke, Syngenta Crop Protection, Inc., Greensboro, NC), and paraquat dichloride (Gramoxone Inteon, Sygenta Crop Protection, Inc., Greensboro, NC). Insecticides, defoliants, and growth regulators were applied as needed according to standard production guidelines for Mississippi. Due to the lack of an in-furrow insecticide in the nontreated subplots, early-season thrips were managed with acephate (Orthene 90 S, Valent U.S.A. Corporation, Walnut Creek, CA; $0.2 \mathrm{~kg} / \mathrm{ha}$ ). Dates of importance pertaining to planting, harvest, nematicide application, and sampling are shown in Table 1 .

Ten soil cores $(2.5 \mathrm{~cm}$ in diameter and $25.4 \mathrm{~cm}$ deep) were collected randomly from the center two rows of each subplot at planting, midseason, and harvest. Samples were stored at $13^{\circ} \mathrm{C}$ until extraction [31], with an understanding of some nematode population loss during storage [32]. Reniform nematodes were extracted from $200 \mathrm{~cm}^{3}$ of soil by Seinhorst elutriation [33], followed by sucrose centrifugation using a $454 \mathrm{~g} / \mathrm{L}$ sugar solution [34]. Reniform nematodes per liter of soil were calculated after counting the nematodes in one-sixth of a partitioned petri dish with a stereomicroscope.

Cotton plots were harvested with a Case 2022 spindletype picker (Case International Harvester, Racine, WI) customized for harvesting test plots. The center two rows of each 4-row plot were harvested and weighed.

Data were evaluated to determine possible interactions between field, cultivar, and nematicide. Field, a variable that included both seasonal and location differences, was considered a random-effect parameter while testing all possible interactions of fixed effects. Assuming field effect was random allowed inferences over a range of experimental conditions [35]. Data were combined across fields only when no statistically significant interactions involving fields were detected. Statistical analysis was completed using the PROC MIXED procedure of SAS (SAS Institute Inc., Cary, NC). Means separation using differences of least squares means was accomplished using the macro PDMIX800 [36] to convert mean separation output to letter groupings. Replications (nested within field) and associated interactions were considered random effects. Tolerance indices were analyzed with fixed effects of cultivar.

Tolerant cultivars are defined as those that yield well even while supporting reniform nematode reproduction. Therefore, reproductive indices (RIs) were calculated for each subplot as

$$
\begin{aligned}
& \mathrm{RI}=\mathrm{Pf} / \mathrm{Pi} \text {, where, } \\
& \mathrm{Pf}=\text { final population and } \\
& \mathrm{Pi}=\text { initial population }
\end{aligned}
$$

over a given time period. To analyze population changes for early and late season periods, late season RI is calculated using $\mathrm{Pf} / \mathrm{Pm}$ (final population/midseason population), where Pm is substituted for Pi. Early season RI is calculated using $\mathrm{Pm} / \mathrm{Pi}$ (midseason population/initial population) [37, 38]. RI values greater than 1.0 indicate that the nematode population is increasing in that plot.

Differences in seed cotton yield between nematicidetreated and -nontreated plots were determined using ANOVA. For plots that did not experience an increase in yield from the nematicide application, tolerance to the reniform nematode was further described in terms of a tolerance index 
TABle 1: Planting, nematicide application, harvest, and nematode sampling dates for a field study evaluating cotton cultivars for tolerance to reniform nematode conducted in four fields at the Mississippi State University Delta Research and Extension Center in Stoneville, MS, in 2006 and 2007.

\begin{tabular}{|c|c|c|c|c|}
\hline \multirow{2}{*}{ Activity } & \multicolumn{4}{|c|}{ Field } \\
\hline & 4 & Barn & 1 & 12 \\
\hline $\begin{array}{l}\text { Planting, initial nematicide application, } \\
\text { initial reniform nematode sampling }\end{array}$ & 22 May 2006 & 24 May 2006 & 7 May 2007 & 7 May 2007 \\
\hline Second nematicide application & $10 \mathrm{Jul} 2006$ & $10 \mathrm{Jul} 2006$ & 18 Jun 2007 & 18 Jun 2007 \\
\hline Midseason reniform nematode sampling & $15 \mathrm{Jul} 2006$ & $15 \mathrm{Jul} 2006$ & 2 Aug 2007 & 2 Aug 2007 \\
\hline Harvest & 6 Sep 2006 & 27 Sep 2006 & 12 Nov 2007 & 12 Nov 2007 \\
\hline Final reniform nematode sampling & 18 Oct 2006 & 18 Oct 2006 & 12 Nov 2007 & 12 Nov 2007 \\
\hline
\end{tabular}

TABle 2: Significance levels for main effects and their interactions for early and late season reniform nematode reproductive indices (RI), seed cotton yield, and tolerance index (TI) in a field study at the Delta Research and Extension Center in Stoneville, MS, in 2006 and 2007.

\begin{tabular}{lcccc}
\hline Main effect $^{\mathrm{v}}$ & $\begin{array}{c}\text { Early } \\
\text { season RI }\end{array}$ & $\begin{array}{c}\text { Late } \\
\text { season RI }\end{array}$ & $\begin{array}{c}\text { Seed cotton } \\
\text { yield }\end{array}$ & TI $^{\mathrm{z}}$ \\
\hline Cultivar $(C)$ & 0.0357 & 0.3410 & $<0.0001$ & 0.0821 \\
Field $(F)$ & 0.0038 & 0.0092 & $<0.0001$ & 0.0005 \\
$C \times F$ & 0.1824 & 0.3114 & 0.0014 & 0.1874 \\
Nematicide $(N)$ & 0.0594 & 0.4338 & $<0.0001$ & - \\
$N \times F$ & 0.3922 & 0.6995 & $<0.0001$ & - \\
$C \times N$ & 0.5128 & 0.7363 & 0.3237 & - \\
$C \times N \times F$ & 0.1937 & 0.2647 & 0.4574 & - \\
\hline
\end{tabular}

${ }^{\mathrm{v}}$ Fixed effects are the main effects of cultivar $(C)$ and nematicide $(N)$ and all interactions of those main effects; random variables are field $(F), C \times F$, $N \times F$, and $C \times N \times F$.

${ }^{\mathrm{w}}$ Early season RI $=\mathrm{Pm} / \mathrm{Pi}=$ (midseason reniform nematode count)/(planting reniform nematode count).

${ }^{\mathrm{x}}$ Late season $\mathrm{RI}=\mathrm{Pf} / \mathrm{Pm}=$ (harvest reniform nematode count $) /($ planting reniform nematode count).

${ }^{y}$ Seed cotton yield taken from the middle two rows of subplots.

${ }^{\mathrm{z}} \mathrm{TI}=[($ seed cotton yield in nontreated plot $) /($ seed cotton yield in nematicide-treated plot) $] * 100$.

(TI) as reported by Koenning et al. [13]. The TI describes cotton yield response to nematicide application in plots infested with reniform nematode, where TI values increase as tolerance increases. The TI is calculated for each cultivar as

$$
\mathrm{TI}=\left(\frac{\text { yield in nontreated plot }}{\text { yield in nematicide-treated plot }}\right) * 100 .
$$

\section{Results}

3.1. Treatment Effects. The significance levels for main effects and their interactions are given in Table 2 for early and late season RI, seed cotton yield, and TI. Differences among cultivars with respect to early season RI were significant at $P \leq 0.05$ and differences in TI were significant at $P \leq$ 0.10 . Significant effects of nematicide treatment on early season RI $(P \leq 0.10)$ were noted. Significant differences
TABLE 3: Early season reniform nematode reproductive index (RI) for 13 cultivars in a field study at the Delta Research and Extension Center in Stoneville, MS, in 2006 and 2007; data averaged across fields and nematicide treatments.

\begin{tabular}{|c|c|c|}
\hline \multirow{2}{*}{$\begin{array}{l}\text { Cultivar } \\
\text { Croplan Genetics } 3520 \text { B2RF }\end{array}$} & \multicolumn{2}{|c|}{ Early season $\mathrm{RI}^{\mathrm{w}}$} \\
\hline & 1.69 & $b c^{x}$ \\
\hline Deltapine 20B & 1.82 & $\mathrm{bc}$ \\
\hline Deltapine $445 \mathrm{BG} / \mathrm{RR}^{\mathrm{y}}$ & 2.38 & $\mathrm{abc}$ \\
\hline Deltapine 449 BG/RR & 3.27 & $\mathrm{a}$ \\
\hline Deltapine 455 BG/RR & 2.34 & bc \\
\hline Deltapine 488 BG/RR & 1.91 & bc \\
\hline DES $119^{\mathrm{z}}$ & 1.92 & $\mathrm{bc}$ \\
\hline DynaGrow 2520 B2RF & 2.20 & $\mathrm{bc}$ \\
\hline Fibermax 960 B2R & 1.95 & $\mathrm{bc}$ \\
\hline Phytogen 370 WR & 1.56 & c \\
\hline Phytogen 485 WRF & 2.14 & $\mathrm{bc}$ \\
\hline Stoneville 5242 BR & 2.51 & $\mathrm{ab}$ \\
\hline Stoneville 5599 BR & 1.63 & $\mathrm{bc}$ \\
\hline \multicolumn{3}{|c|}{$\begin{array}{l}{ }^{\mathrm{w}} \text { Early season } \mathrm{RI}=\mathrm{Pm} / \mathrm{Pi}=\text { (midseason reniform nematode } \\
\text { count)/(planting reniform nematode count). } \\
{ }^{\mathrm{x}} \text { Means followed by the same letter in the same column are not significant } \\
\text { at the } 0.05 \text { level based on differences of least squares means. } \\
{ }^{y} \text { Control cultivar with respect to yield. } \\
{ }^{\mathrm{z}} \text { Tolerant control. }\end{array}$} \\
\hline
\end{tabular}

among cultivars and nematicide treatments were observed for seed cotton yield $(P \leq 0.05)$, though responses were influenced by interactions $(P \leq 0.05)$ with the random effect of field. Late season RI was not significantly affected by either cultivar or nematicide. Differences $(P \leq 0.05)$ among fields were detected for all parameters, though this variation was considered a random effect.

3.2. Differences among Cultivars. Early season RI values were highest for "Deltapine 445 BG/RR" (high yield check cultivar), "Deltapine 449 BG/RR," and "Stoneville 5242 BR" (Table 3), though only the early season RI for "Deltapine 449 BG/RR" was significantly higher than the RI on the other 10 cultivars in the test. Although "Phytogen 370 WR" produced the lowest early season RI, it differed significantly 
TABle 4: Seed cotton yield for cultivars in four fields in a field study at the Delta Research and Extension Center in Stoneville, MS, in 2006 and 2007; data are averaged across nematicide treatments.

\begin{tabular}{|c|c|c|c|c|c|c|c|}
\hline \multirow{3}{*}{$\begin{array}{l}\text { Cultivar } \\
\text { Croplan Genetics } 3520 \text { B2RF }\end{array}$} & \multicolumn{7}{|c|}{ Seed cotton yield $(\mathrm{kg} / \mathrm{ha})^{\mathrm{w}}$} \\
\hline & \multicolumn{2}{|c|}{ Field 4} & \multirow{2}{*}{$\frac{\text { Barn Field }}{1971.1}$} & \multicolumn{2}{|c|}{ Field 1} & \multicolumn{2}{|c|}{ Field 12} \\
\hline & 2242.6 & $a b^{x}$ & & 3052.3 & $a b^{x}$ & 3822.1 & $a b c^{x}$ \\
\hline Deltapine 20B & 1602.6 & $\mathrm{~cd}$ & 1863.4 & 2803.8 & $\mathrm{~b}$ & 3156.6 & fg \\
\hline Deltapine 445 BG/RR ${ }^{y}$ & 2015.3 & $\mathrm{abc}$ & 2111.1 & 3225.2 & $\mathrm{a}$ & 3521.9 & cdef \\
\hline Deltapine 449 BG/RR & 2140.9 & $\mathrm{ab}$ & 2149.7 & 2833.5 & $\mathrm{~b}$ & 3492.1 & cdef \\
\hline Deltapine 455 BG/RR & 1943.7 & bc & 1615.2 & 2960.7 & $\mathrm{ab}$ & 3343.5 & efg \\
\hline Deltapine 488 BG/RR & 2103.9 & $\mathrm{ab}$ & 1942.9 & 2298.8 & c & 3081.1 & $\mathrm{~g}$ \\
\hline DES $119^{z}$ & 1686.0 & $\mathrm{~cd}$ & 1789.6 & 2154.6 & c & 2608.7 & $\mathrm{~h}$ \\
\hline DynaGrow 2520 B2RF & 1960.7 & $a b c$ & 2097.1 & 3006.7 & $\mathrm{ab}$ & 3540.9 & bcde \\
\hline Fibermax 960 B2R & 1438.9 & $\mathrm{~d}$ & 1787.5 & 2391.7 & c & 3306.7 & efg \\
\hline Phytogen 370 WR & 2187.0 & $\mathrm{ab}$ & 2184.4 & 3084.4 & $\mathrm{ab}$ & 3955.7 & $\mathrm{a}$ \\
\hline Phytogen 485 WRF & 2147.8 & $\mathrm{ab}$ & 2020.2 & 3107.4 & $\mathrm{ab}$ & 3917.8 & $\mathrm{ab}$ \\
\hline Stoneville 5242 BR & 2363.4 & $\mathrm{a}$ & 2194.5 & 3170.5 & $\mathrm{a}$ & 3776.3 & abcd \\
\hline Stoneville 5599 BR & 1337.7 & $\mathrm{~d}$ & 1806.6 & 2983.9 & $\mathrm{ab}$ & 3427.2 & defg \\
\hline
\end{tabular}

${ }^{\mathrm{w}}$ Seed cotton yield taken from the middle two rows of subplots.

${ }^{\mathrm{x}}$ Means followed by the same letter in the same column are not significantly different at the 0.05 level based on differences of least squares means.

${ }^{y}$ Control cultivar with respect to yield.

${ }^{\mathrm{z}}$ Tolerant control.

TABLE 5: Early season reproductive index and seed cotton yield in a field study at the Delta Research and Extension Center in Stoneville, MS, in 2006 and 2007; data averaged across fields and cultivars.

\begin{tabular}{|c|c|c|c|c|}
\hline Nematicide & Early & $\mathrm{RI}^{\mathrm{x}}$ & Seed cotto & $\mathrm{d}(\mathrm{kg} / \mathrm{ha})^{\mathrm{y}}$ \\
\hline No nematicide & 2.28 & $\mathrm{a}$ & 2466.4 & b \\
\hline $\begin{array}{l}\text { Nematicide } \\
\text { applied }^{z}\end{array}$ & 1.93 & b & 2638.5 & $\mathrm{a}$ \\
\hline
\end{tabular}

${ }^{\mathrm{x}}$ Early season $\mathrm{RI}=\mathrm{Pm} / \mathrm{Pi}=$ (midseason reniform nematode count)/(planting reniform nematode count); means followed by the same letter in this column are not significantly different at the 0.10 level based on ANOVA.

${ }^{y}$ Seed cotton yield taken from the middle two rows of subplots; means followed by the same letter in this column are not significantly different at the 0.05 level based on ANOVA.

${ }^{\mathrm{z}}$ Aldicarb applied in furrow at planting $(0.84 \mathrm{~kg}$ a.i./ha) plus side dress application at pinhead square $(1.17 \mathrm{~kg}$ a.i./ha).

only from "Deltapine 449 BG/RR" and "Stoneville 5242 BR." Differences among cultivars were not observed for late season RI, with values ranging from 1.29 for "Deltapine 449 BG/RR" to 4.18 for "Stoneville 5599 BR." All RI values were greater than 1.0, indicating that all cultivars supported reniform nematode reproduction.

Although seed cotton yields varied among cultivars, response for yield depended upon the field in which the trial was conducted (Table 4). In general, yields tended to be lower in 2006 (Field 4 and Barn Field) compared to in 2007 (Fields 1 and 12). No differences in cultivars were detected for yield in the Barn Field. In the remaining three fields, "Croplan Genetics 3520 B2RF," "Phytogen 370 WR," "Phytogen 485 WRF" and "Stoneville 5242 BR" tended to rank among the highest yielding entries whereas "DES 119" and "Fibermax 960 B2R" tended to rank among the lowest yielding entries.

3.3. Differences among Nematicide Treatments. When averaged across all cultivars, the early season RI for reniform nematode was higher in plots that had not been treated with nematicides than in plots that received nematicide applications (Table 5). Seed cotton yield was higher in plots treated with nematicide (Table 5). Together, yield and RI response served as an indication that conditions conductive for evaluating tolerance had been established. However, because a significant nematicide x field effect was detected, the effect of nematicide application on yield was examined for individual fields (Table 6). No differences in yield were observed between treated and nontreated plots in Field 4, but the remaining fields all had significantly higher seed cotton yields in treated plots than in nontreated plots. Nematicide treatment did not affect late season RI (Table 2).

3.4. Identification of Tolerant Cultivars. All cultivars evaluated supported reniform nematode reproduction, meeting one requirement in defining a tolerant cultivar. Seed cotton yields in nematicide-treated and nontreated subplots for each cultivar are compared in Table 7. Cultivars whose yields were equivalent in treated and nontreated plots met the second criterion in defining a tolerant cultivar. As defined, cultivars considered tolerant to reniform nematode were "Croplan Genetics 3520 B2RF," "Deltapine 20B," "Deltapine 488 BG/RR," “DES 119," "DynaGrow 2520 B2RF," "Fibermax 960 B2R," "Stoneville 5242 BR," and "Stoneville 5599 BR." Tolerance indices (TI) among these cultivars varied little, 
TABLE 6: Effects of nematicide on seed cotton yield in four fields in a field study at the Delta Research and Extension Center in Stoneville, MS, in 2006 and 2007; data are averaged across cultivars.

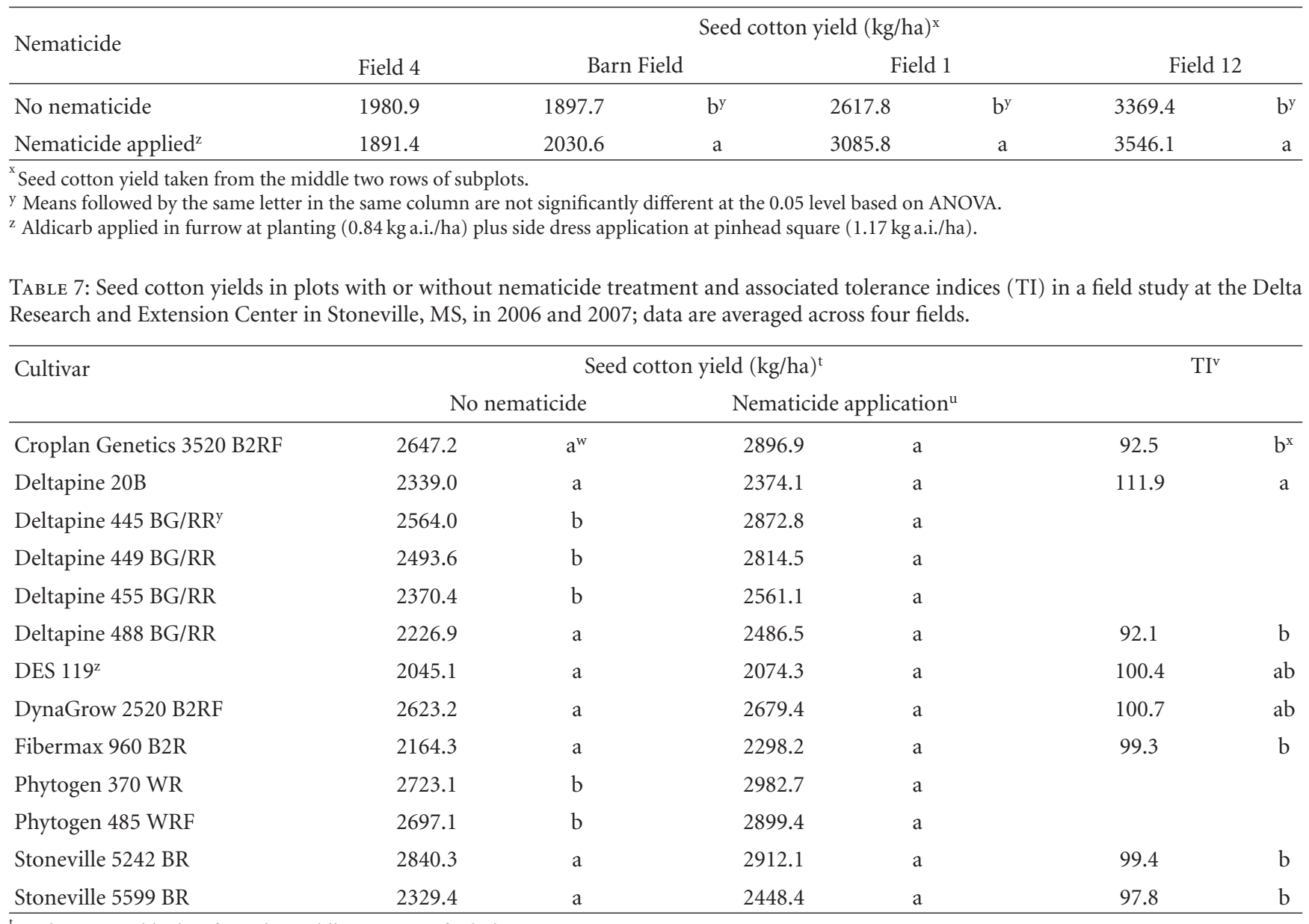

${ }^{\mathrm{t}}$ Seed cotton yield taken from the middle two rows of subplots.

${ }^{u}$ Aldicarb applied in furrow at planting $(0.84 \mathrm{~kg}$ a.i./ha) plus side dress application at pinhead square $(1.17 \mathrm{~kg}$ a.i./ha).

${ }^{\mathrm{v}} \mathrm{TI}=$ tolerance index $=[($ seed cotton yield in nontreated plot $) /($ seed cotton yield in nematicide-treated plot $)] * 100$; values listed only for cultivars meeting tolerance criteria.

${ }^{\text {w}}$ For each cultivar, mean seed cotton yields followed by the same letter are not significantly different from each other at the 0.05 level based on ANOVA.

${ }^{x}$ Means followed by the same letter in the TI column are not significantly different at the 0.10 level based on differences of least squares means.

${ }^{y}$ Control cultivar with respect to yield.

${ }^{\mathrm{z}}$ Tolerant control.

with "Deltapine 20B", "DES 119", and "DynaGrow 2520 B2RF" having the highest TI values (Table 7).

\section{Discussion}

"Croplan Genetics 3520 B2RF," "Deltapine 20B," "Deltapine 488 BG/RR," “DES 119" (tolerant control), "DynaGrow 2520 B2RF," “Fibermax 960 B2R," “Stoneville 5242 BR," and "Stoneville 5599 BR" were identified as tolerant to reniform nematode in this study. Because yields were not significantly reduced in reniform nematode infested soils, any of these cultivars should be considered a suitable candidate for use in infested fields. However, yield potential must also be considered when selecting a cultivar for production. Of the tolerant cultivars identified, "Croplan Genetics 3520 B2RF" and "Stoneville 5242 BR" consistently ranked among the highest yielding entries in the study. Cotton growers in the Mississippi Delta farming on reniform nematode infested soils could realize immediate benefits from using identified tolerant cultivars. Growers outside this region should consult their local variety test extension publication and use those results in combination with reports of tolerance to make the best cultivar choice possible for their farm. The utility of tolerant cultivars that did not rank among the top yielding cultivars, such as "DES 119" and "Fibermax 960 B2R," should not be dismissed from consideration. In soils were a high number of reniform nematodes is the most significant yield limiting factor, growers may still benefit from a tolerant, albeit lower yielding cultivar.

In this study, six of the 12 cultivars evaluated demonstrated levels of tolerance to reniform nematode, along with the tolerant control "DES 119." More tolerant cultivars were identified in the present study than what has previously been 
reported in similar studies ( 2 of 34 entries reported by Usery et al. [21], and 3 of 39 entries reported by Stetina et al. [20]), but the reason for this is unclear. The presence of a significant nematicide $\mathrm{x}$ field interaction suggests that environment plays an important role in the ability to detect tolerance. Cotton breeders may have intentionally selected for tolerance to reniform nematode in recent years as they developed lines adapted to the Midsouth. Because tolerant lines do suffer the same yield loss as their susceptible counterparts, perhaps indirect selection for tolerance has occurred during the development of new, high yielding cultivars in a region where selection pressure from reniform nematode is common.

Previous studies have relied upon a single RI over the course of the growing season $[15,16]$ to identify host tolerance to nematodes. However, using two RI over the course of the growing season allows for verification of nematicide efficacy in addition to characterizing reniform nematode reproduction [13, 20, 21, 39]. Differences between nematicide-treated and -nontreated plots for early season RI indicated that reniform nematode reproduction was suppressed in the presence of aldicarb in this study. However, it should be noted that aldicarb is used for control of thrips, aphids, fleahoppers, leafminers, mites, overwintering boll weevil, plant bugs, and whiteflies, as well as nematodes [40]. Because of this, alternative insecticides were applied across the field as needed to provide protection to plots that were not treated with aldicarb. Reddy et al. [41] showed aldicarb has a direct regulatory effect on plant growth when pests are absent. The addition of aldicarb also changes root distribution, with deeper root systems under ideal water and nutrient environment [42]. These additional aldicarb properties may have influenced seed cotton yield in this study to favor aldicarb treated plots in some instances.

Until cultivars with resistance to reniform nematode are commercially available, tolerant cultivars could serve to reduce economic losses associated with cotton production in reniform nematode infested fields. As such, there is a need to continue programs directed at identifying current cultivars and advanced breeding lines tolerant to reniform nematode.

\section{Disclosure}

The mention of trade names or commercial products in this publication is solely for the purpose of providing specific information and does not imply recommendation or endorsement by the US Department of Agriculture (USDA) or Mississippi State University.

\section{Acknowledgment}

This research was partially funded by USDA, Agricultural Research Service Project no. 6402-22000-005-06S. USDA is an equal opportunity provider and employer.

\section{References}

[1] D. Blasingame, W. Gazaway, K. Lawrence et al., "Cotton disease loss estimate committee report-2008," in Proceedings of the Beltwide Cotton Conferences, vol. 1, pp. 94-96, 2009.
[2] T. L. Kirkpatrick and C. S. Rothrock, Compendium of Cotton Diseases, The American Phytopathological Society Press, St. Paul, Minn, USA, 2nd edition, 2001.

[3] A. F. Robinson, "Reniform in U.S. cotton: when, where, why, and some remedies," Annual Review of Phytopathology, vol. 45, pp. 263-288, 2007.

[4] J. L. Starr, S. R. Koenning, T. L. Kirkpatrick, A. F. Robinson, P. A. Roberts, and R. L. Nichols, "The future of nematode management in cotton," Journal of Nematology, vol. 39, no. 4, pp. 283-294, 2007.

[5] S. R. Stetina, L. D. Young, W. T. Pettigrew, and H. A. Bruns, "Effect of corn-cotton rotations on reniform nematode populations and crop yield," Nematropica, vol. 37, no. 2, pp. 237248, 2007.

[6] D. J. Chitwood, "Nematicides," in Encyclopedia of Agrochemicals (3), pp. 1104-1115, John Wiley \& Sons, New York, NY, USA, 2003.

[7] J. D. Mueller, "The use of Temik 15G on cotton and soybean in the southeast," in Proceedings of the Beltwide Cotton Conferences, vol. 1, pp. 208-214, 2011.

[8] A. F. Robinson, C. G. Cook, and A. E. Percival, "Resistance to Rotylenchulus reniformis and Meloidogyne incognita race 3 in the major cotton cultivars planted since 1950," Crop Science, vol. 39, no. 3, pp. 850-858, 1999.

[9] N. D. Dighe, A. F. Robinson, A. A. Bell, M. A. Menz, R. G. Cantrell, and D. M. Stelly, "Linkage mapping of resistance to reniform nematode in cotton following introgression from Gossypium longicalyx (Hutch. \& Lee)," Crop Science, vol. 49, no. 4, pp. 1151-1164, 2009.

[10] G. B. Romano, E. J. Sacks, S. R. Stetina et al., "Identification and genomic location of a reniform nematode (Rotylenchulus reniformis) resistance locus (Ren ${ }^{\text {ari }}$ ) introgressed from Gossypium aridum into upland cotton (G. hirsutum)," Theoretical and Applied Genetics, vol. 120, no. 1, pp. 139-150, 2009.

[11] O. A. Gutiérrez, A. F. Robinson, J. N. Jenkins et al., "Identification of QTL regions and SSR markers associated with resistance to reniform nematode in Gossypium barbadense L. accession GB713," Theoretical and Applied Genetics, vol. 122, no. 2, pp. 271-280, 2011.

[12] G. N. Agrios, Plant Pathology, Academic Press, San Diego, CA, USA, 4th edition, 1997.

[13] S. R. Koenning, K. R. Barker, and D. T. Bowman, "Tolerance of selected cotton lines to Rotylenchulus reniformis," Journal of Nematology, vol. 32, no. 4, pp. 519-523, 2000.

[14] D. T. Bowman and D. P. Schmitt, "Screening cotton for tolerance to Hoplolaimus columbus," Plant Disease, vol. 78, no. 7, pp. 695-697, 1994.

[15] C. G. Cook, A. F. Robinson, and L. N. Namken, "Tolerance to Rotylenchulus reniformis and resistance to Meloidogyne incognita race 3 in high-yielding breeding lines of upland cotton," Journal of Nematology, vol. 29, no. 3, pp. 322-328, 1997.

[16] R. F. Davis and O. L. May, "Relationships between tolerance and resistance to Meloidogyne incognita in cotton," Journal of Nematology, vol. 35, no. 4, pp. 411-416, 2003.

[17] A. S. Hill, O. L. May, and J. D. Mueller, "Evaluation of tolerance to Meloidogyne incognita and Hoplolaimus columbus in cotton genotypes," Journal of Nematology, vol. 26, p. 550, 1994.

[18] S. R. Koenning, "Tolerance to Hoplolaimus columbus in glyphosate-resistant, transgenic soybean cultivars," Journal of Nematology, vol. 34, no. 4, pp. 370-373, 2002.

[19] D. P. Schmitt and J. L. Imbriani, "Management of Hoplolaimus columbus with tolerant soybean and nematicides," Annals of Applied Nematology, vol. 1, pp. 59-63, 1987. 
[20] S. R. Stetina, G. S. Sciumbato, J. A. Blessitt, and L. Young, "Cotton cultivars evaluated for tolerance to reniform nematode," Plant Health Progress, 2009.

[21] S. R. Usery, K. S. Lawrence, G. W. Lawrence, and C. H. Burmester, "Evaluation of cotton cultivars for resistance and tolerance to Rotylenchulus reniformis," Nematropica, vol. 35, no. 2, pp. 121-133, 2005.

[22] C. G. Cook and A. F. Robinson, "Registration of RN96425, RN96625-1 nematode resistant cotton germplasm lines," Crop Science, vol. 45, pp. 1667-1668, 2005.

[23] J. E. Jones, J. P. Beasley, J. L. Dickson, and W. D. Caldwell, "Registration of four cotton germplasm lines with resistance to reniform and root-knot nematodes," Crop Science, vol. 28, pp. 199-200, 1988.

[24] P. S. Thaxton, T. P. Wallace, N. W. Buehring, M. Shankel, W. E. Clark, and S. Shi, "Mississippi cotton variety trials, 2006," Information Bulletin 433, Mississippi Agricultural \& Forestry Experiment Station, Mississippi State University, Mississippi State, MS, 2007, http://msucares.com/pubs/ infobulletins/ib0433.pdf.

[25] C. Overstreet, "Survey of reniform nematodes in 2001," Louisiana Agricultural Cooperative Extension Service Update No. 3, Baton Rouge, LA, USA, 2001.

[26] S. R. Koenning, "Economics and ecology put to use-action thresholds," in Proceedings of the Beltwide Cotton Conferences, vol. 1, pp. 143-147, 2002.

[27] G. L. Sciumbato, J. A. Blessitt, and D. Blasingame, "Mississippi cotton nematode survey: results of an eight-county survey," in Proceedings of the Beltwide Cotton Conferences, vol. 1, p. 451, 2004.

[28] D. Blasingame and G. Sciumbato, "Varietal reaction to the reniform nematode of cotton," in Proceedings of the Beltwide Cotton Conferences, vol. 1, p. 180, 1991.

[29] S. Nichols, T. P. Wallace, N. W. Buehring, P. Thaxton, and J. R. Johnson, “Mississippi cotton variety trials, 2005," Information Bulletin 427, Mississippi Agricultural \& Forestry Experiment Station, Mississippi State University, Mississippi State, MS, 2006, http://msucares.com/pubs/infobulletins/ib0427.pdf.

[30] D. L. Blasingame, W. Gazaway, P. Goodell et al., Cotton Nematodes Your Hidden Enemy: Identification and Control, The National Cotton Council, Memphis, TN, USA, 2002.

[31] K. R. Barker, C. J. Nusbaum, and L. A. Nelson, "Effects of storage temperature and extraction procedure on recovery of plant-parasitic nematodes from field soil," Journal of Nematology, vol. 1, pp. 240-247, 1969.

[32] K. S. Lawrence, G. W. Lawrence, and E. van Santan, "Effect of controlled cold storage on recovery of Rotylenchulus reniformis from naturally infested soil," Journal of Nematology, vol. 37, no. 3, pp. 272-275, 2005.

[33] J. W. Seinhorst, "Methods for the extraction of Heterodera cysts from not previously dried soil samples," Nematologica, vol. 10, pp. 87-94, 1964.

[34] W. R. Jenkins, "A rapid centrifugal-flotation technique for separating nematodes from soil," Plant Disease Reporter, vol. 48, p. 692, 1964.

[35] S. G. Carmer, W. E. Nyquist, and W. M. Walker, "Least significant differences in combined analyses of experiments with two- or three-factor treatment designs," Agronomy Journal, vol. 81, pp. 665-672, 1989.

[36] A. M. Saxton, "A macro for converting mean separation output to letter groupings in Proc Mixed," in Proceedings of the 23rd SAS Users Group International, pp. 1243-1246, 1998.
[37] F. G. W. Jones, D. M. Parrott, and G. J. S. Ross, "The population genetics of the potato cyst nematode, Heterodera rostochiensis: mathematical models to simulate the effects of growing eelworm-resistant potatoes bred from Solanum tuberosum spp. andigena," Annals of Applied Biology, vol. 60, pp. 151-171, 1967.

[38] J. W. Seinhorst, "The relationships between population increase and population density in plant parasitic nematodes," Nematologica, vol. 13, pp. 157-171, 1967.

[39] S. R. Koenning and D. T. Bowman, "Cotton tolerance to Hoplolaimus columbus and impact on population densities," Plant Disease, vol. 89, no. 6, pp. 649-653, 2005.

[40] J. E. Slosser, "Influence of planting date and insecticide treatment on insect pest abundance and damage in dryland cotton," Journal of Economic Entomology, vol. 86, pp. 12131222, 1993.

[41] V. R. Reddy, Z. Wang, and K. R. Reddy, "Growth responses of cotton to aldicarb and temperature," Environmental and Experimental Botany, vol. 38, no. 1, pp. 39-48, 1997.

[42] V. R. Reddy, K. R. Reddy, and Z. Wang, "Temperature and aldicarb effects on cotton root growth and development," Biotronics: Environmental Control and Environmental Biology, vol. 26, pp. 1-11, 1997. 


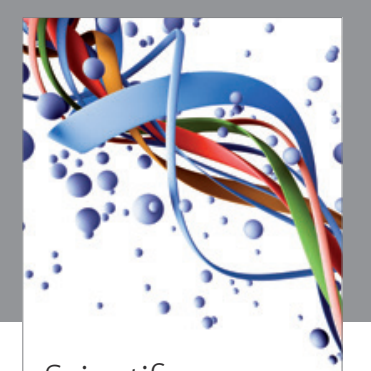

Scientifica
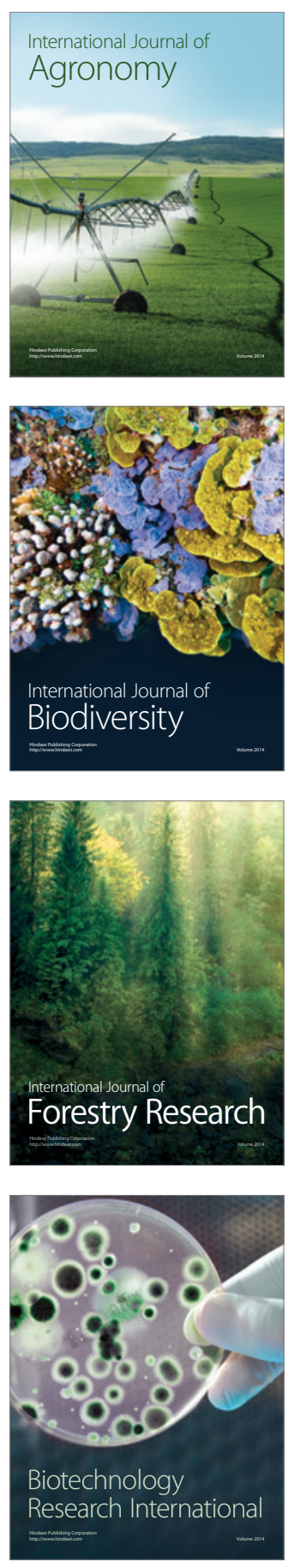
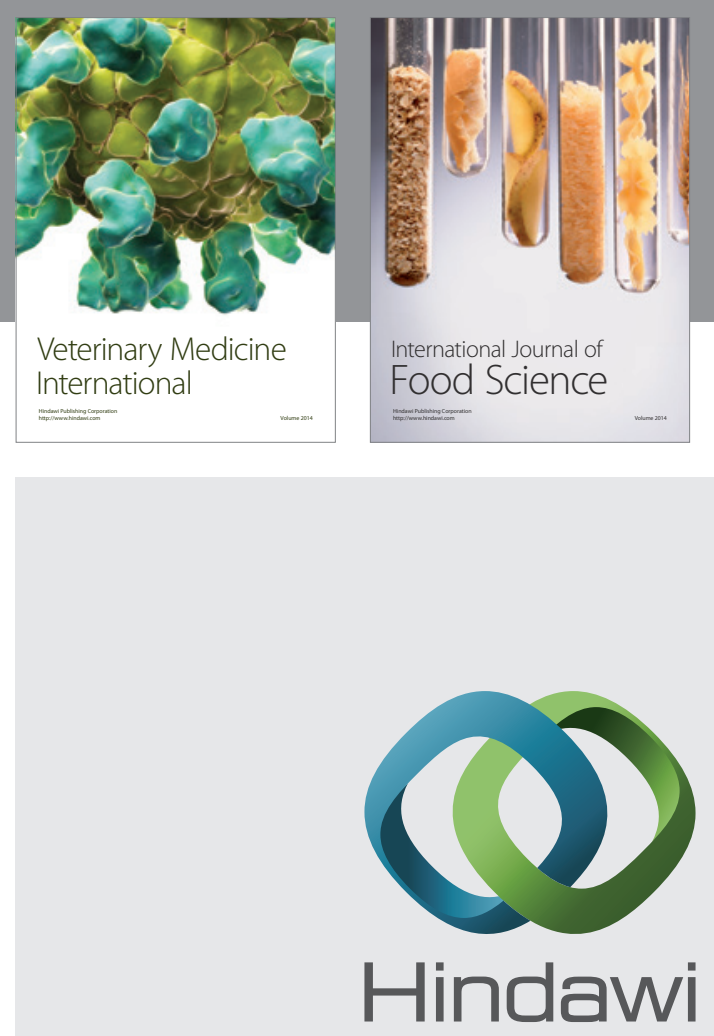

Submit your manuscripts at

http://www.hindawi.com
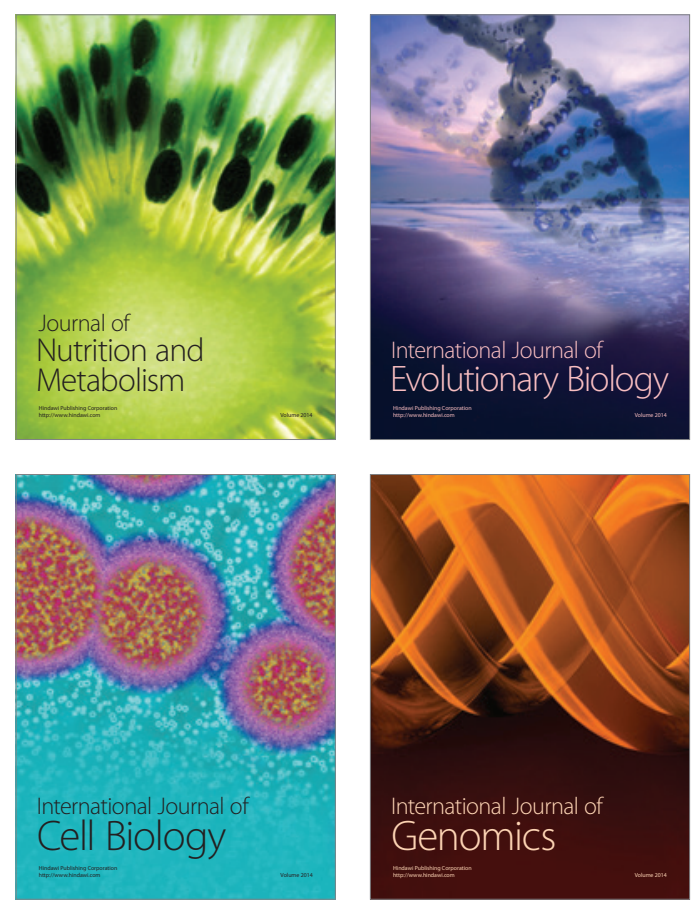
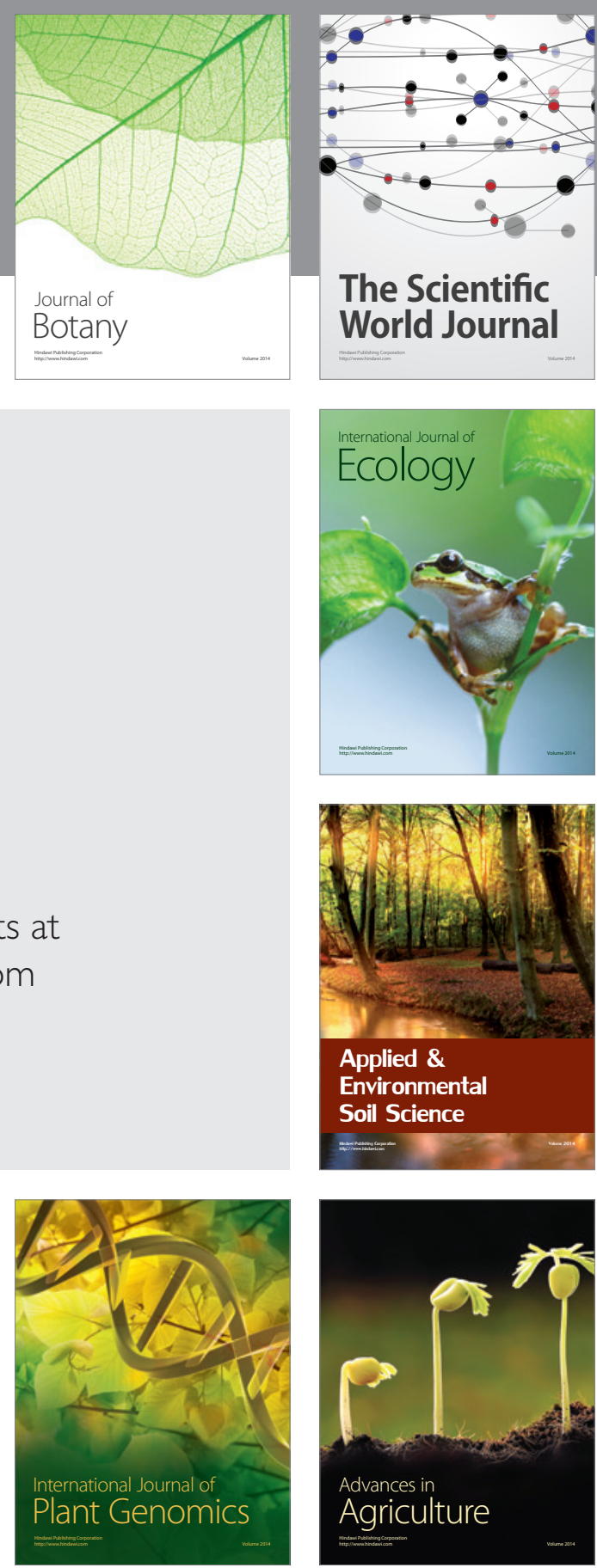

The Scientific World Journal
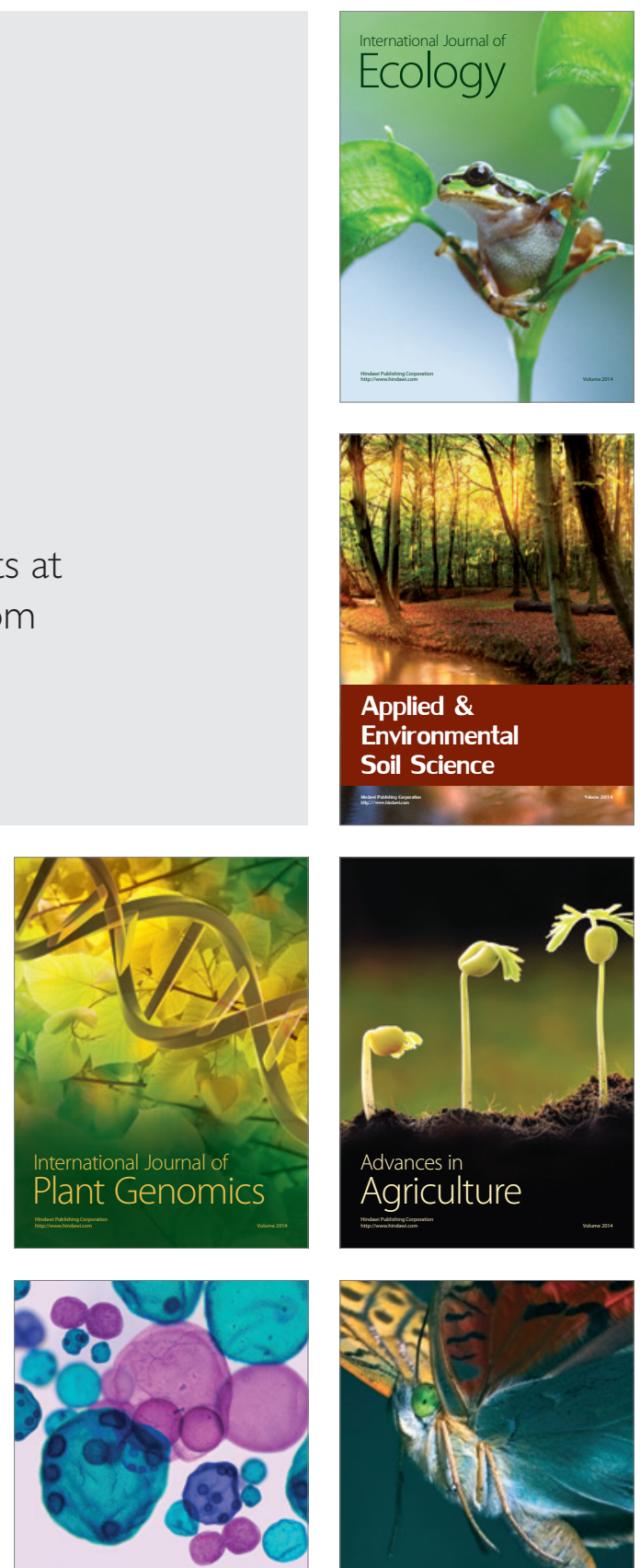

International Journal of Microbiology

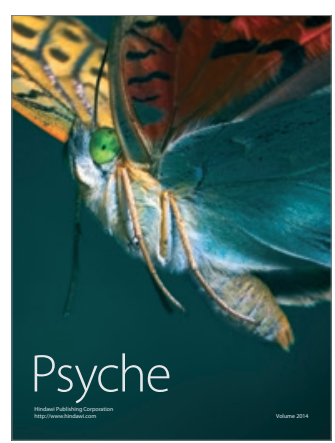

